\title{
Prophet Muhammad's Linguistic Etiquette
}

\author{
Wafa Abu Hatab* \\ Department of English, Zarqa University, Jordan
}

Received on: 24-8-2020

Accepted on: 31-12-2020

\begin{abstract}
The present study tackles the concept of linguistic etiquette in Prophet Muhammad's Hadith adopting a sociolinguistic perspective that examines the relationship between linguistic etiquette and politeness. The study adopts Leech's (1983) model of politeness to investigate maxims of politeness and politeness scales in Prophet Muhammad's spoken discourse. Data consisted of Hadith on morals and linguistic etiquette reported in reliable Hadith books such as Al-Bukhari, Muslim and Abu Dawood. Analyzed Hadith displayed a clear observation of maxims of tact, generosity, approbation, modesty and sympathy. Further examples from Hadith manifested observance of cost-benefit, optionality, indirectness, authority and social distance scales.
\end{abstract}

Keywords: Hadith, Linguistic Etiquette, Politeness, Politeness Maxims, Politeness Scales, Prophet Mohammad.

\section{1-Introduction}

Michael M. Hart (1978) placed Prophet Muhammad first in his book, The 100: A Ranking of the Most Influential Persons in History. According to Hart, Prophet Muhammad "was the only man in history who was supremely successful on both the religious and secular levels... It is this unparalleled combination of secular and religious influence which I feel entitles Muhammad to be considered the most influential single figure in human history." 33

Prophet Muhammad was born in 570 in Mecca, a city in Saudi Arabia that was considered the religious capital for Arabs at that time. Prior to his prophethood, Prophet Muhammad was referred to in Mecca as 'AlSadeq', 'Alameen', that is the truthful and the trustworthy. At the age of forty, the revelation was sent to him by Angel Gabriel thus marking a new era in the history of Arabia as well as human history. Prophet Mohammad's inaugural call for Islam was directed to people in Mecca who were asked to quit the worship of idols and worship God to affirm His Oneness and perform good deeds. The Qur'an, the book revealed to Prophet Muhammad, states that he is sent as a mercy for all creation:

"And we have not sent you (O Muhammad) but as mercy for all creations."(21:107).

"We have not sent you (O Muhammad) but a universal messenger to all people" (34:28).

๑ 2022 JJMLL Publishers/Yarmouk University. All Rights Reserved,

${ }^{*}$ Doi: https://doi.org/ 10.47012/jjmll.14.1.7

*This research is funded by the Deanship of Scientific Research at Zarqa University, Jordan.

* Corresponding Author: whatab@zu.edu.jo 
Such universality was understood at the very start by Prophet Muhammad who considered morals as a basic pillar in this universality. His morality is therefore stressed in the Qur'an "And indeed, you are of great integrity and morals." (68:4). Thomas Carlyle (1897, 63) (reprinted 2010) comments on Prophet Muhammad's spoken discourse stating that

But, from an early age, he had been remarked as a thoughtful man. His companions named him "Al Amin, The Faithful." A man of truth and fidelity; true in what he did, in what he spoke and thought. They noted that he always meant something. A man rather taciturn in speech; silent when there was nothing to be said; but pertinent, wise, sincere, when he did speak; always throwing light on the matter. This is the only sort of speech worth speaking!

The present study investigates Prophet Muhammad's spoken discourse proposing that it provides comprehensive practice of politeness and linguistic etiquette. It explores aspects of linguistic etiquette in the narrated Hadith as well as Prophet Muhammad's biography. Applying Leech's (1983) model of politeness, the study attempts to answer the following questions:

1. How are the maxims of politeness observed in Prophet Muhammad's Hadith?

2. What politeness scales can be found in Prophet Muhammad's Hadith?

\section{Theoretical Background}

The word etiquette was borrowed from French in the eighteenth century. According to Hitchings (2013), the word "etiquette" was first used in the collection of letters written by the fourth Earl of Chesterfield Philip Stanhope to his son, in which he gave instructions on how to become a gentleman. The word "etiquette" was associated at that time with code of conduct and self-control. Gradually, the word acquired other collocations that are associated with speech style that involves the appropriate linguistic choice on semantic, syntactic and sociolinguistic levels.

Linguistic etiquette is defined by Kasper $(1998,374)$ as 'the practice in any speech community of organizing linguistic action so that it is seen as appropriate to the current communicative event'. The most relevant sociolinguistic concept to etiquette is politeness; sometimes linguistic etiquette is equated with the term linguistic politeness. Despite the fact that there are cultural universals such as gendered roles, religious rituals, moral sentiments and linguistic universals, each culture has its own concept of what is socially acceptable and what is not. Consequently, our linguistic behavior is governed by social norms and conceptions that determine how to be linguistically polite.

The theoretical ground for linguistic etiquette is based on studies by Grice (1975), Leech (1983) and Brown and Levinson (1987). For Grice, effective communication results from speakers' cooperative efforts to make their speech understood following what he refers to as maxims of speech. These are the maxims of quality, quantity, relevance and manner. Speakers should make their speech as informative as required to observe the maxim of quantity. The maxim of quality requires the speaker to be honest and not say what he believes to be false or lack adequate evidence. Maxim of relevance demands that the speaker responds in a relevant manner so if he is asked a question he responds with a relevant answer. 


\section{Prophet Muhammad's Linguistic Etiquette}

The final maxim is the maxim of manner which calls for avoiding obscurity and ambiguity of expressions.

Leech (1983:104) defines politeness, as 'forms of behavior that establish and maintain comity', following what he refers to as 'the politeness principle': minimize the expressions of impolite beliefs and maximize the expressions of polite beliefs.'(81). His contribution to politeness theory is well recognized for the introduction of politeness maxims that are practiced to avoid conflict among speakers considering the speaker's feelings and attitudes. These maxims are stated as follows (107-135):

1- The Tact maxim: minimizing cost to other and maximizing benefit to other. For example, the request 'Could I join your zoom meeting?' shows that the speaker is trying to avoid any imposition on the hearer by using the indirect instead of a direct speech act to issue his request. If the speaker says 'Add me to the zoom meeting', he will maximize cost to the hearer who will view such an utterance as impolite.

2- The Generosity Maxim: minimizing benefit to self and maximizing cost to self as in the following invitation where the speaker is maximizing benefit to the hearer by inviting him to his party.

We would love to see you at our party.

3- The Approbation Maxim: minimizing dispraise of other and maximizing praise. This maxim is visible in illocutionary functions of thanking and complementing where the speaker maximizes praise of his addressee and minimizes dispraise as in the following examples:

What a good solution! You are a very practical person.

I would like to thank you for your invitation. It really made my day.

4- The Modesty Maxim: the participants must minimize praise of self and maximize dispraise of self. Leech $(1983,136)$ states that 'the understatement of one's generosity is shown to be quite normal, and indeed, conventional, in contrast to the exaggeration of one's generosity as in the following example:

Please accept this small gift as a token of our esteem.

5- The Agreement Maxim: maximizing agreement between self and other people and minimizing disagreement between self and other as shown by the following example:

A: It was a fantabulous party yesterday, wasn't it?

B: Yes, definitely.

6- The Sympathy Maxim: minimizing antipathy between self and other and maximizing sympathy between self and other. This maxim is very common in condolences as in the following example:

I am so sorry to hear about your loss.

Politeness for Leech operates on various scales that aim at saving participant's face. These scales are identified as follows:

1. Cost - benefit scale (of an act to the addresser and the addressee). The addresser measures the cost and benefit to him and his addressee.

2. Optionality Scale: concerns the amount of choice granted to the addressee by the addresser. 
Abu Hatab

3. The indirectness scale is both speaker and hearer-centered. It is related to the speaker's indirectness and the hearer's inferential strategies to arrive at the speaker's intended meaning.

4. Authority /power scale deals with the role of authority one participant has in identifying the social distance

5. The social distance scale is associated with levels of solidarity affected by age, status and familiarity.

(Leech 1983, 123-127)

Politeness scales are to be distinguished from politeness strategies. While a politeness scale operates on a scale of maximizing benefit and minimizing loss, politeness strategies deal with the techniques used by the speaker to save the hearer's positive face when a face-threatening act is involved. Brown and Levinson's (1987) view of politeness revolves around the concept of face which is one's self-image. They maintain that people are either interested in being left free from imposition, in such a case the term negative politeness is used to describe such a desire. The other one is the speakers' desire to be socially connected and this is referred to as positive politeness. Any act that saves the addressee's face is described as a face-saving act whereas any act that does not consider other interlocutors' face is called a facethreatening act. Brown and Levinson $(1987,92)$ classify politeness strategies into four: Off Record, Baldon Record, Positive, and Negative Politeness.

\section{Review of Related Literature}

Linguistic etiquette has been tackled from different perspectives related to structure, use as well as semantic and pragmatic implications. A considerable part of research focused on the formulaic aspect of linguistic etiquette associated with a given communicative function (Coulmas 1981, 2005; Ferguson 1966; Goffman 1974 and Kasper 1990). A shift to the analysis of the communicative aspect of linguistic etiquette is marked by studies that tackle turn-taking and interruption in communicative functions (Ferguson 1976 and Laver 1981). Akindel (2007), for example, focuses on the role of linguistic etiquette in establishing interpersonal relations. Pragmatic aspects of linguistic etiquette of speech act theory and speech genres were tackled at a later stage (Blum-Kulka 1984, and Brown and Levinson, 1987).

Most studies on politeness in Arabic discourse dealt with modern colloquial Arabic. For instance, Badarneh (2010) examined the pragmatic functions of diminutives in colloquial Jordanian Arabic applying Brown and Levinson's model. The study revealed that diminutives are used in both positive and negative politeness contexts. Other studies focused on colloquial Jordanian Arabic such as Al-Qudah, 2017; Abushihab, 2015; Bani Mofarrej \& Al-Abed Al-Haq, 2015; Al-Harahsheh, 2014, Almutlaq \& Jarrah, 2013; Al-Khawaldeh \& Zegarac, 2013; Al-Sobh, 2013 and Rababa'h \& Malkawi, 2012. Some studies on politeness in Arabic focused on cultural aspects such as Samarah (2015) who studied politeness from a cultural perspective deriving examples mainly from Egyptian Arabic. His study revealed that politeness expressions that show the effect of religion are more frequent than expressions affected by social conventions. Bouchara (2015) investigated the role of religion in choosing politeness strategies in Moroccan Arabic focusing on the use of Qur'anic verses and religious words in the speech act of greeting. Another study on Moroccan Arabic was conducted by Alaoui (2011) on politeness in English and Arabic. 


\section{Prophet Muhammad's Linguistic Etiquette}

Studies on politeness in standard Arabic are very scarce. Elsaadany (2010) examined the major interrogative functions in Prophet Muhammad's Hadith, basing his study on Hadith in Sahih Al-Bukhari. Al-Khatib (2012) explored politeness in the Holy Quran from a socio-pragmatic perspective where Quranic verses were analyzed following Brown and Levinson's theory of politeness and Leech's maxims of politeness. Al Momani and Rabab'a, (2018) study dealt with politeness strategies and the representation of women in the Holy Qur'an.

\section{Rationale and Significance}

Most Arab and Muslim scholars praise Prophet Mohammad's eloquence. Studying the linguistic features of his Hadith is, therefore, expected to provide deep insights into syntactic, semantic and pragmatic features of standard Arabic. While most literature on Hadith studies tackles Hadith either from a religious or legislative perspective, linguistic accounts of Prophet Mohammad's discourse are not given enough attention.

To the researcher's best knowledge, published studies on Prophet Mohammad's politeness strategies are very scarce. The present study is expected to bridge this research gap by investigating the politeness maxims and scales in Prophet Mohammad's discourse by analyzing chosen examples of his Hadith.

\section{Research Methodology}

The present study is confined to the analysis of the linguistic rather than the social aspects of etiquette in Prophet Mohammad's Hadith. The selection criterion is based on Hadith dealing with morals, greetings, daily dialogue, eating and thanking. Only reliable Hadith books are consulted such as AlBukhari, Al-Baihaqi, Muslim and Abu Dawood. Leech's (1983) model is adopted in the analysis of politeness maxims and scales. The first stage of analysis encompassed maxims of tact, generosity, approbation, modesty, agreement and sympathy. This stage is followed by the analysis of politeness scales of cost - benefit, optionality, indirectness, authority /power and social distance scale.

\section{Results and Discussion}

Prophet Muhammad was born in the Arab Peninsula where Arabic was the main medium of communication. As a child, he was sent to the most eloquent tribes to acquire the most eloquent variety from its native speakers. In the Holy Quran, the Prophet is addressed as one who speaks Arabic fluently.

"Which the trustworthy (Gabriel) has brought down upon your heart in the plain Arabic language."

(The Qur'an, 26:193-195)

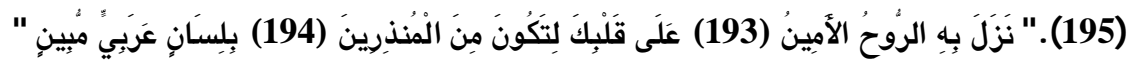

Prophet Muhammad comments on his linguistic competence saying: "I have been given the ability to express comprehensive meanings using the shortest expressions." This refers to the ability to be precise but not at the expense of meaning avoiding complicated vocabulary. Others said that that phrase could refer to the Holy Qur'an which is still considered a linguistic miracle to Arabs who were challenged to come up with a single ayah similar to the Qur'an. When it was revealed to Prophet Muhammad, the non- 


\section{Abu Hatab}

believers were challenged to compose a single ayah but they could not though they were famous for their high linguistic competence. They used to have poetry competitions and poetic masterpieces used to be hung on the walls of the Ka'ba'. The Quran was revealed to the Prophet over twenty-three years, thirteen in Mecca and ten in Medina. At that time, he had to memorize it by heart. This must have had a great effect on his linguistic competence.

Prophet Muhammad was also reported to have said that he was the most eloquent among Arabs because he was from the Quraish tribe and that he was breastfed at Bani Sa'd's, a tribe known for its eloquence. At that time it was the custom to send babies to the desert to be stronger and to acquire pure Arabic from the Bedouins who were considered the origin of Arabs so those who wanted to master Arabic had to live with them. This gave Prophet Muhammad a golden opportunity to experience all lifestyles starting with the simplicity and tranquility of the Bedouin life accompanied with pure Arabic then moving to Mecca. At that time Mecca was a famous village for trade and agriculture and there the Prophet had the chance to widen his linguistic repertoire before he moved to Medina which represented civilization and architecture. This built the Prophet's ability to deal with people from rural, urban and Bedouin areas depending on his first-hand experience with their residents.

Prophet's wife Aisha said that the Prophet's speech was clearly understood; it was not too fast and everyone listening to him would memorize everything he said. He would repeat a word three times to be understood. His wife Aisha said that his speech was clear so if one wanted to count his words he would have been able to. He was known for his long silence and he would not speak unless there was a need to speak. He used to start his speech with the name of Allah and conclude with praising Him. His speech was neither redundant nor incomplete, it was quiet and he never looked for people's faults or overpraised them. He would observe social distance and not ask about things that do not concern him and would never insult anyone.

Al-Baihaqi (2003, 31) reported that Prophet Muhammad avoided three things: argumentation, talking too much and interfering in what is of no importance to him. He also avoided three other things: he never talked of anyone, he never mocked anyone and he never spoke of anyone's fault in front of others, nor did he criticize anyone. He spoke only about things that he hoped to be rewarded for. He was extremely patient when his addresser spoke a different dialect and would not interrupt the speaker until he completed his statement. Anas Bin Malik who was the Prophet's servant for ten years said that Prophet Muhammad did not swear at anyone or was rude, nor did he curse. (Al-Bukhari 2012, 36)

Motivated by the international nature of his mission, Prophet Muhammad was also known for his ability to communicate with non-Arabs at that time such as the Kings of Rome and Persia. He exerted tremendous efforts to transform the people of Arabia at that time from a tough and ignorant society into a civilized one. A considerable portion of his Hadith tackled people's daily activities teaching them how to be civilized when dealing with others focusing on linguistic as well as non-linguistic aspects of communication. 


\section{Prophet Muhammad's Linguistic Etiquette}

\subsection{Politeness Maxims in Prophet Mohammad's Discourse}

This section provides an analysis of the maxims of politeness in Prophet Muhammad's spoken discourse (Hadith) in light of Leech's (1983) model of politeness with examples from Hadith on greeting, thanking and daily communication. In the following examples, Prophet Muhammad asks people to greet first then resume dialogue when coming across each other. Greeting accompanied with a cheerful face is valued. Here the tact maxim is observed thus maximizing benefit to the other giving him/her the feeling of welcome and belonging. The maxim of generosity is observed as well when Prophet Muhammad calls for greeting everyone including strangers, thus minimizing benefit to self and maximizing it to the other.

1. "Do not belittle any good deed, even meeting your brother with a cheerful face." (Muslim 2014, 485).

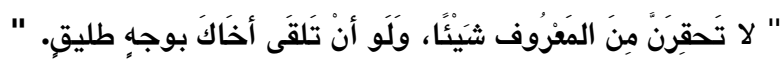

2. "What Islamic traits are the best?" The Prophet said, "Feed the people, and greet those whom you know and those whom you do not know.' (Abu Dawood 2009, 542).

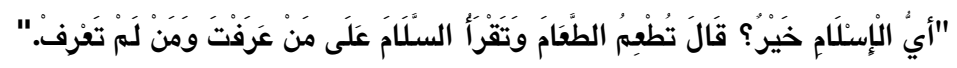

Prophet Muhammad even went to the point where he put rules saying that the rider of a horse or a camel greets the walker while the walker greets the one who is setting and the young greets the old. These rules take into consideration the maxim of modesty where the greeter minimizes self-praise and maximizes praise of the other as well as sympathy which minimizes antipathy and maximizes sympathy. The one riding a horse or camel is more comfortable than the one walking on foot, so he is expected to show more sympathy and greet the other one. Moreover, he should display humbleness and greet the others and not show off and walks away as shown by the following Hadith:

3. "The rider should greet with peace those who are walking, those who are walking should greet those who are sitting, and a small group should greet a larger group."(Al-Bukhari 2012, 144).

$$
\text { "يُسلُم الراكب على الماشي، والماشي على القاعد، والقليل على الكثير. " }
$$

When asked about the best thing to do as a Muslim, Prophet Muhammad responded: "by offering food to people and greeting them even if you do not know them." He considered greeting as one's path to paradise and employed indirect speech acts as a politeness strategy that saves the addressee's face, avoiding direct advice and simply saying : "Shall I guide you to something if you do, you will all love each other and win paradise: greet each other by saying Assalamu Alaykum." The Prophet encouraged his companions to greet each other using the phrase Assalamu Alaykum Warahmatu Allahi Wabaraktuhu, literally, may you have peace, blessing and mercy from Allah. He was reported by Muslim to take into consideration the time of the day so if it is night his greeting would not disturb the sleepy and would be clear enough for the awake to hear it. This is clear evidence of observing the maxim of sympathy which maximizes sympathy between self and the other and minimizes antipathy between self and the other. Consequently, if a group passes by another group, it is enough for one member of the group to greet with salam (peace) and for one of the addressed group to respond. Prophet Muhammad encouraged Muslims to greet their families as they enter their homes saying that this would bless them and their families. He used to greet children if he came across them playing thus observing the maxim of modesty where the old 


\section{Abu Hatab}

greets the young. In this case, Prophet Muhammad himself greets the children and by doing so the modesty maxim is observed maximizing praise to the other.

Asking for permission to enter someone's house should be preceded by the greeting 'Assalamu Alaykum.' A man wanted to get into a house where Prophet Muhammad was setting. He asked for permission saying 'shall I get in? 'The Prophet taught him to say : Assalamu Alaykum, shall I enter? Then he allowed him to enter. (Abu Dawood 2009, 480). When asking for permission to enter someone's house, one should mention his/her name if he/she is asked, not simply say it's me. Such advice takes into consideration the maxim of agreement which calls for maximizing agreement with the other and minimizing disagreement. One should seek the addressee's agreement before entering his house and by doing so the tact maxim is also observed, thus minimizing cost to the host who might not want to give the permission. Another aspect of greetings is to say to the one who sneezes if he praises God: May God have mercy on you. This goes with the tact maxim which maximizes the benefit to the addressee with the addressor's supplicating to God to have mercy on him and minimizing any feeling of embarrassment replacing it with the feeling of understanding and belonging.

Prophet Muhammad urged Muslims to visit the sick considering this as one of the rights each Muslim has towards the other. He was reported to have made several supplications to God to cure the sick and taught Muslims what to say. For example, he taught a companion named Othman bin Abi Al'as to say "in the name of Allah", three times then seven times: "I seek refuge in Allah from what I suffer and fear." He also encouraged those who visit the sick to tell them they are fine and they still have a long life to live as this will help them recover. Teaching the guest what to say goes with the tact maxim thus minimizing cost and maximizing benefit so that the sick person is comforted. Such teachings go in line with the sympathy maxim that maximizes sympathy between the guest and the host.

Having in mind the moral mission of establishing a harmonious society, Prophet Muhammad exerted tremendous efforts to teach people how to deal with each other properly tackling all aspects of daily life. His Hadith and biography are full of examples that stress the significance of moral behavior and being tactful when dealing with others. Virtue and piety are praised by Prophet Muhammad who said that these traits lead to paradise while gossip and trying to stir disputes among others are strongly condemned. People are encouraged to smile at each other as they meet, greet then talk. Interrupting the other before he finishes his talk is unacceptable. Hadith books narrate the story of Utba bin Abi Rabi'a, one of the elites at Mecca who volunteered to negotiate with Prophet Muhammad so that he quits Islam. The Prophet gave him all the time to say all that he wanted to say though his speech was a mixture of threats and temptations. As he finished, the Prophet asked him "Have you finished Abu Alwaleed?" When his addressee confirmed he started reciting the Quran. Leech's modesty and approbation maxims are clearly observed in this incident. Prophet Mohammad did not interrupt, thus modesty maxim is clearly displayed and further fostered by addressing Utba with a favored nickname, 'Abu Alwaleed' since it is the custom in the Arab culture to address the man with 'Abu' (father of) followed by the names of his eldest son. Such behavior is seen as an act of respect and by doing so the tact maxim is observed. 


\section{Prophet Muhammad's Linguistic Etiquette}

Prophet Muhammad stressed the importance of showing gratitude to anyone who does us any favor. He said he who does not thank people for doing him any good, does not thank Allah, i.e. he does not show gratitude to Allah. On another occasion, he said that the one who expressed his gratitude for a meal he eats has the same rank as a person fasting patiently. Degrees of thanking were also taught, the best one is to say 'May Allah reward you with all good' as the most expressive form of appreciation thus maximizing benefit to the addressee.

\subsection{Politeness Scales in Prophet Mohammad's Discourse}

Politeness can be measured on five scales following Leech's (1983) model. As far as the profit- cost scale is concerned, an addresser measures the amount of cost and benefit to him and his addressee and tries to increase benefit to the addressee and minimize the cost to be polite. Prophet Mohammad once said that Allah hates the one whose speech is so artificial that fakes eloquence where he rolls his tongue as the cow does. (Abu Dawood 2009, 353). Such a manner of speech increases cost to the addressee who will struggle to understand the addressor's message. In the same vein, Prophet Mohammad warned against threatening people with bad words. He once addressed his wife Aisha saying that the worst people are those who are respected just for fear of their tongues, i.e. to avoid their tongues. (Abu Dawood 2009, 171). Such people are impolite since they do maximize the benefit to themselves at the expense of their addressees. Another case where the cost to the addressee is minimized and benefit is maximized is by keeping his/her secret. Prophet Muhammad was reported as saying that the worst man on Judgment day is a husband who reveals his wife's secrets. (Muslim, 2014, Vol.4:61). The benefit to the addressee is also stressed when the Prophet considered breaking a promise, lying and treason as signs of hypocrisy as the following Hadith shows:

4. "Among the signs of a hypocrite are three, even if he fasts and prays and claims to be a Muslim: when he speaks he lies, when he gives a promise he breaks it, and when he is trusted he betrays."(Al -Bukhari 2012, 213).

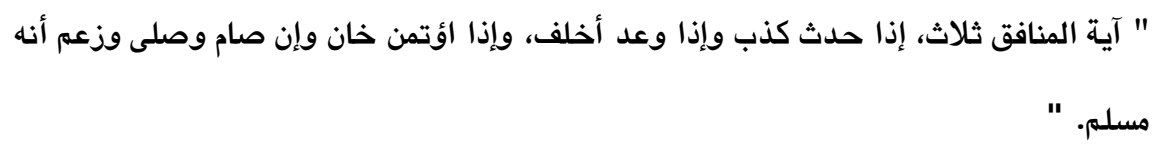

Minimizing cost to the addressee involves clarity of speech. Prophet Muhammad used to repeat what he says three times until he was understood. He would even greet people three times.(Al-Bukhari 2012, 265). Many Prophetic Hadiths stress the importance of keeping one's tongue from harming others. For example, the Muslim is defined as the one from whose tongue and hand the Muslims are safe. (AlBukhari 2012, 197).

The optionality scale deals with the degrees of options the speaker gives to the hearer and the choices allowed to him. Prophet Mohammad was very gentle with all people, Muslims and non- Muslims alike. He considered individual differences when he addressed others and tried his best to give them options. In the following Hadith Muslims are given three options to deal with evil depending on their abilities. 
Abu Hatab

5. "Whoever among you sees evil, let him change it with his hand. If he is unable to do so, then with his tongue. If he is unable to do so, then with his heart, and that is the weakest level of faith."

(Muslim 2014, 400)

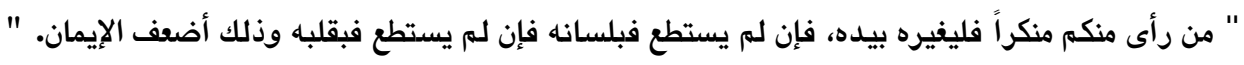

Optionality scale was also observed by Prophet Mohammad when he was once invited to a meal and was followed by a man. The Prophet addressed his host saying "This man has followed us, if you allow him in, he would join us, otherwise he would leave." The host said "I allow him, Messenger of Allah." (Al-Bukhari 2012, 470)

The Prophet gave his host the option to accept or reject as a sign of politeness and taught Muslims to ask for permission before entering someone's house and explained its etiquette asking people to greet first then ask for permission. He told Muslims not to give permission to one who does not greet before asking for permission. The guest asks for permission three times, if he gets no response, this is taken as a no from the host. If two people are speaking to each other, a third should ask for permission to join. Addressees have the option to allow him in or reject. The Prophet said "A man is not allowed to interfere in a dialogue between two without their permission." (Abu Dawood 2009, 2140)

There is a direct correlation between politeness and indirectness. According to this scale, the higher the indirectness, the more polite the utterance is where indirect requests are viewed as the most polite and direct ones as the least. Prophet Muhammad used to be indirect when he advised people so as not to offend them. Anas ibn Malik reported once that some of the Prophet's companions once asked about deeds that he performed in private. Some said, "I will not marry women." And some said, "I will not eat meat." And some said, "I will never sleep in a bed." The Prophet praised and glorified Allah, and said:

6. "What is the matter with some people who say this? I pray and I sleep, I fast and I break fasting, and I marry women. Whoever does not desire my Sunnah does not belong to me."

(Al-Bukhari 2012, 6).

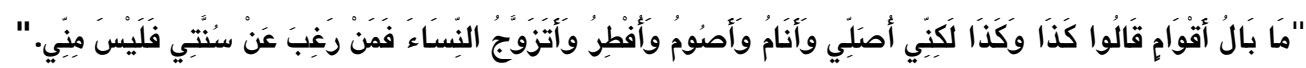

When Prophet Muhammad wanted to advise he would start with the question: shall I guide you or shall I inform you as in the following example.

7. "You will not enter Jannah until you believe, and you will not believe until you love one another.

Shall I inform you of something which, if you do, you will love one another? Promote greetings amongst yourselves." (Abu Dawood 2009, 490)

" لا تدخلوا الجنة حتى تؤمنوا، ولا تؤمنوا حتى تحابوا، أولا أدلكم على شيء إذا فعلتموه تحاببتم؟ أفشوا السلام

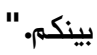

The advice was always indirectly given thus the Prophet would say why would people do this or that without identifying the person. He once addressed people who gaze at the sky when they pray saying "What's wrong with people who look at the sky during the prayer."(Al-Bukhari 2012, 660). He saw them 
and did not want to offend them and saved their face by addressing them indirectly thus leaving the chance for the addressee to infer the intended meaning.

Authority /power scale involves using politeness strategies to mark authority such as the use of an address form that denotes the higher status of the addressee. This scale was observed by Prophet Muhammad in his letters to the kings and emperors. He addressed King of Persia at that time as 'the great leader of the Persians.' (Ibn Sa'ed 1990, 360) as shown in the following example:

"بسم الله الرحمن الرحيم، من محمد رسول الله إلى كسرى عظيم فارس. "

8. "In the name of Allah, the Most Compassionate, the Most Merciful. From Muhammad, the Messenger of Allah, to Kisra, the great (leader) of the Persians."

Prophet Mohammad acknowledged the political power of his addressee and introduced himself at the same time as the Messenger of Allah, thus giving justification for contacting the King of Persia :

$$
\text { "وأدعوك بدعاية الله، فإني أنا رسول الله إلى الناس كافة. " }
$$

\section{9. "Under the Command of Allah, I invite you to Him as I was sent as a messenger for all people."}

In his message to Hercules, Prophet Muhammad acknowledged the status of Hercules as the king of the Byzantines and introduced himself as "the worshipper of Allah.” [Sahih Al-Bukhari, 2012 Vol.1:4-5] opening his letter as follows:

$$
\text { "بسم الله الرحمن الرحيم من محمد رسول الله إلى هرقل عظيم الروم." }
$$

10.'In the name of Allah, the Most Compassionate, the Most Merciful, from Muhammad, Worshiper and Messenger of Allah to Heraclius the Great of the Romans."

By recognizing the royal status of his addressee addressing him as 'the Great of the Romans', Prophet Mohammad wanted to give his followers at that time a practical lesson on how to take people's authority and power into consideration regardless of their religious beliefs.

The last politeness scale is that of social distance that is governed by differences between addressor and addressee in terms of age, gender, and social status. According to Leech $(1983,126)$

"The overall degree of respectfulness, for a given speech situation, depends largely on relatively permanent factors of status, age, degree of intimacy, etc., but also, to some extent, on the temporary role of one person relative to another."

Prophet Mohammad encouraged Muslims to maintain a balance between observing the privacy of interlocutors and involving them in dialogues so that they do not feel offended. One should not sit between two people without their permission and if there are three persons, two should not speak privately ignoring the third since doing so according to Prophet Muhammad hurts the feelings of the third. Social distance is thus respected by not intruding on a talk without being invited. Observing others' social distance and respecting it is stressed and connected to good faith, so if you have good faith, you do not intrude on others' private matters. Prophet Muhammad encouraged Muslims to mind their own business and not to interfere or spy on others and considered such behavior as a sign of good faith.

Speaker's age, social status and intellectual level should be taken into consideration when we address others. Prophet Muhammad excluded the ones who do not show mercy towards the little ones and respect 


\section{Abu Hatab}

for the old from the Muslim community saying that "Anyone who does not show mercy to the young and realize the status of the old does not belong to us." (Abu Dawood 2009, 299)

Prophet Muhammad encouraged Muslims to give people the status and respect they deserve and stressed the importance of giving the old people all respect they deserve saying that "Any young who honors the old for his age will be rewarded by the same as he gets old."(Al-Tarmathi 1996, 194). Prophet Muhammed used the most appropriate term of address to denote status and solidarity. He addressed Omar bin Al-Khattab, one of his companions and the second caliph, with the term brother, a thing that was reported by Omar to mean the world.

\section{Conclusion}

The present study investigated politeness maxims and scales in the spoken discourse of Prophet Muhammad. It applied Leech's (1983) model of politeness to a sample of Hadith that was reported about Prophet Mohammad in Hadith books. The study showed that the five maxims of politesses were observed by Prophet Muhammed in his speech with Muslims as well as non -Muslims. Politeness scales were also manifested in Prophet Muhammad's teachings to minimize cost and maximize benefit to addressees. Optionality scale was also observed in Hadith so that addressees did not have the feeling that they were always obliged. The authority scale was displayed in Hadith that provided advice on how to address people with higher authority and observe the social distance. Further research is recommended on the pragmatic aspects of Prophet Muhammad's discourse. The discourse of other Prophets could also be studied from a pragmatic as well as a sociolinguistic perspective. Furthermore, the findings of the present study could have implications for future research on politeness in various forms of religious discourse as well as other discourse genres. 
Prophet Muhammad's Linguistic Etiquette

$$
\begin{aligned}
& \text { آداب السلوك اللفوي (الإتكيت) في الخطاب النبوي } \\
& \text { وفاء أبو حطب } \\
& \text { قسم اللفة الإنجليزية، جامعة الزرقاء ، الأردن }
\end{aligned}
$$

تتناول هذه الدراسة مفهوم الإتكيت اللفوي في السنة النبوية من منظور علم اللفة الاجتماعي في محاولة لبحث العلاقة بين آداب السلوك اللفوي ونظرية التهذيب بناء على نموذج (1983) Leech لدراسة قواعد السلوك المهذب ومقاييسه في الخطاب النبوي. تكونت عينة الدراسة من الأحاديث حول الآداب والإتيكيت اللفوي كما نقل في كتب الحديث الموثوقة عند البخاري، ومسلم، وأبو داود. وقد بينت الدراسة من خلال الأحاديث التي تم تحليلها أن جميع قواعد السلوك المهذب كالذوق، والكرم، والموافقة، والتواضع والتعاطف والمقاييس الخاصة بالفائدة، والاختيارية، والأسلوب غير المباشر، واحترام السلطة والمسافة الاجتماعية كلها أمور قد تجلت في الخطاب النبوي. الكلمات المفتاحية: الحديث، الإتكيت اللفوي، التهذيب، قواعد التهذيب، مقاييس التهذيب، النبي محمد . 
Abu Hatab

\section{References}

Abu Dawood, Sulayman. 2009.Sunan Abi Dawood.(سنن ابي داود) Damascus: Dar Alresalh Al'almeyya.

Abushihab, Ibrahim. 2015. Contrastive Analysis of Politeness in Jordanian Arabic and Turkish. Theory and Practice in Language Studies 5 (10): 2017-2022. https://doi.org/10.17507/ tpls.0510.06

Akindel, Dele Femi. 2007. Lumela/Lumela: A Socio-Pragmatic Analysis of Sesotho Greetings. Nordic Journal of African Studies 16 (1): 1-17

Al-Abed Al-Haq, Fawwaz and Alaa Ibraheem Qura'an. 2014. Prophet Mohammad's Letters from a Critical Discourse Perspective. US-China Foreign Language 12 (6):443-463.

Alaoui, Sakina. 2011 Politeness Principle: A Comparative Study of English and Moroccan Arabic Requests, Offers and Thanks. European Journal of Social Sciences 20 (1):7-15

Al-Baihaqi, Ahmad.2003. AlSunan Alkubra. (السنن الكبرى). Beirut: Dar Alkutub Al'elmeyya

Al-Bukhari, Muhammad. 1997. Sahih Aladab Almufrad (صحيح الادب المفرد).Amman: Dar Alseddiq.

Al-Bukhari, Muhammad 2012. Sahih Al-Bukhari. (صحيح البخاري).Cairo: Dar Altaseel.

Al-Harahsheh, Ahmad. 2014. The Sociolinguistic Roles of Silence in Jordanian Society. Journal of Advances in Linguistics 1 (1): 16-23.

Al-Khatib, Mahmoud. 1995. Sociolinguistic View of Linguistic Taboo in Jordanian Arabic. Journal of Multilingual \& Multicultural Development 16 (6): 443-457.

Al-Khatib, Mahmoud A. 2012. Politeness in the Holy Qur'an: A Sociolinguistic And Pragmatic Perspective. Intercultural Pragmatics 9 (4): 479-509.

Al-Khawaldeh, Nisreen, and Vladimir Zegarac. 2013. Gender and the Communication of Gratitude in Jordan. Open Journal of Modern Linguistics 3: 268-287. https://doi.org/10.4236/ojml. 2013.33035 (accessed March 7, 2020)

Al Momani, Kawkib, Fathi Migdadi, and Eman Rabab'a. 2018. Politeness Strategies and The Representation of Women in The Holy Qur' an. Intercultural Pragmatics 15 (3): 409-435.

Almutlaq, Husein. and Mufleh Jarrah. 2013. Salutations in Jordanian Arabic: A Sociolinguistic Perspective. International Journal Of Social Science 4 (15): 111-114.

Al-Qudah, Mahmoud. 2017. The Jordanian Terms of Address: A Sociopragmatic Study. SHS WebConf. 37, 01080. ERPA. https://doi.org/10.1051/shsconf/20173701080(accessed March 7, 2020)

Al-Sobh, Mahmoud. 2013. An Analysis of Apology as a Politeness Strategy Expressed by Jordanian University Students. International Journal Of Humanities And Social Science 3 (2): 150-154.

Al-Tarmathi, Muhammad. 1996.Sunan Al-Tarmathi. (سنن الترمنذي)Beirut: Dar Algharb Allislami

Badarneh, Muhammad. 2010. The Pragmatics of Diminutives in Colloquial Jordanian Arabic. Journal of Pragmatics 42 (1): 153-167

Bani Mofarrej, Omar, and Fawwaz Al-Abed Al-Haq. 2015. A Sociolinguistic Study of Euphemistic Death Expressions in Jordanian Arabic. Arab World English Journal (AWEJ) 3 (6): 110-130.https://doi.org/ 10.24093/awej/vol6no2.9(accessed March 9, 2020) 
Prophet Muhammad's Linguistic Etiquette

Blum-Kulka, Shoshana. 1987. Indirectness and Politeness in Requests: Same or Different? Journal of Pragmatics 11 (2): 131-146.

Bouchara, Abdelaziz. 2015. The Role of Religion in Shaping Politeness in Moroccan Arabic: The Case of the Speech Act of Greeting and its Place in Intercultural Understanding and Misunderstanding. Special Issue: Politeness in Africa. Journal of Politeness Research 11 (1): 71-98. doi: 10.1515/pr-2015-0004(accessed February 20, 2020)

Brown, Penelope, and Stephen Levinson. 1987. Politeness: Some Universals in Language Usage (Studies in Interactional Sociolinguistics. Cambridge: Cambridge University Press.

Carlyle, Thomas. 2010. The Hero as Prophet. Mahomet: Islam. In The Works of Thomas Carlyle (Cambridge Library Collection - The Works of Carlyle), ed. H. Traill 42-77. Cambridge: Cambridge University Press.

Coulmas, Florian. 1981. "Poison To Your Soul": Thanks and Apologies Contrastively Viewed. In Conversational Routine, ed. Coulmas, Florian, 69-91. The Hague: Mouton.

Coulmas, Florian. 2005. Linguistic Etiquette in Japanese Society. In Politeness In Language: Studies In Its History. Theory and Practice, ed. Richards, Watts, Sachiko. Ide \& Konrad. Ehlich, 299-323. Berlin/New York: Mouton De Gruyter.

Elsaadany, Kamel.2010. Functions of Interrogation in the Hadith: A Sociolinguistic Study. RASK, vol.32:3-41

Ferguson, Charles A. 1976. The Structure and Use Of Politeness Formulas. Language in Society 5 (2): 137-151

Hart, Michael H. 1978. The 100: A Ranking of the Most Influential Persons in History. New York: Hart Publishing Company.

Hitchings, Henry. 2013. Sorry! The English and Their Manners. London: Farrar Straus and Giroux.

Ibn Sa'id, Muhammad. 1990. Altabaqt Alkubra. (لطبقات الكبرى) Beirut: Dar Elkutub El'lmeyya.

Grice, Herbert Paul. 1975. 'Logic and Conversation'. Syntax and semantics, Vol. 3, Speech Acts, ed. Peter Cole, and Jerry. L. Morgan, 41-58. New York: Academic Press.

Goffman, Erving. 1974. Frame Analysis: An Essay on the Organization of Experience. Cambridge: Cambridge Univ. Press.

Kasper, Gabriele. 1998. "Linguistic Etiquette." In The Handbook of Sociolinguistics, ed, Florian,Coulmas, 374-85,Oxford: Blackwell..

Laver, John. (1981). Linguistic Routines and Politeness in Greeting and Parting. In Conversational Routines, ed. Florian. Coulmas, 289-304. The Hague: Mouton.

Leech, Geoffrey 1983. Principles of Pragmatics. London: Longman

Muslim,Abu elhusain. 2014. Sahih Muslim.(صحيح مسله) Medina: Islamic University.

Rababa'h, Mahmoud, and Nibal Malkawi. 2012. The Linguistic Etiquette of Greeting and Leave-Taking in Jordanian Arabic. European Scientific Journal 8 (18): 14-28.

Samarah, Abdallah. 2015. Politeness in Arabic Culture. Theory and Practice In Language Studies 5 (10): 2005-2016. 